\title{
Mandado de Segurança Contra Ato Judicial e o CPC de 2015
}

\author{
Writ of Mandamus against Judicial Act and CPC 2015
}

Teresa Arruda Alvim

'Pontifícia Universidade Católica de São Paulo - PUC-SP, Brasil

A Calmon de Passos:

Calmon de Passos foi um homem especial. Homem culto, muito mais do que um processualista, era um pensador do direito. Um orador incrivelmente sedutor, que arrancava das plateias aplausos por minutos inteiros. Inteligente, contundente, apaixonado.

Conheci-o quando menina nos primeiros anos de vigência do CPC de 1973. Era impossível não se apaixonar! do juiz.

Um dos temas dos quais tratou com a lucidez costumeira foi o mandado de segurança contra atos

\section{1) Uma pincelada de caráter histórico - às fases}

O mandado de segurança contra atos do juiz sempre foi, sob certo aspecto, mal visto.

Um dos objetivos da Reforma do CPC de 1973, ocorrida em 1995, ao conceber um novo regime para o agravo de instrumento, foi justamente o de restringir o uso do mandado de segurança com a finalidade de imprimir-lhe efeito suspensivo.

De fato, como o agravo de instrumento era um recurso, no regime anterior à Reforma de 1995, que se caracterizava justamente, salvo em casos muito excepcionais, por não ter efeito suspensivo, o uso do mandado de segurança, para suspender os efeitos da decisão impugnada, se tornou comum, e essa suspensão, por meio da liminar, concedida no bojo daquela ação, fazia as vezes do efeito suspensivo que o recurso de agravo não tinha, e não podia ter. ${ }^{1}$

Como a possibilidade de concessão de efeito suspensivo ao agravo de instrumento foi facilitada, naturalmente a quantidade de agravos tramitando nos tribunais aumentou consideravelmente. Diante disso, foi realizada mais uma reforma, pela Lei 11.187/2005, que estabeleceu que, em regra, o agravo seria retido, somente se admitindo o agravo de instrumento em hipóteses excepcionais (art. 522 do CPC/1973).

$1 \quad$ Antes da Reforma, havia decisões isoladas em que se concedia efeito suspensivo ao agravo, fora dos casos do art. 558, que, como se viu, tinha caráter absolutamente excepcional. Veja-se o texto seguinte: "Se o juiz pode reformar a decisão, que é o mais, pode suspender-lhe a execução, que é o menos, dando efeito suspensivo ao agravo de instrumento, conduta recomendável em caso de possibilidade de dano irreparável, caso provido o recurso, ou esvaziamento do próprio recurso, chegando à decisão do Órgão Recursal, em caso de provimento, quando o fato já estará consumado. A sensibilidade do magistrado, no exame do caso concreto, dispensará impetração de muitos mandados de segurança que visam a obtenção de efeito suspensivo em recursos que não o tem. Agravo improvido" (TARS, 4. a CC, Ag. 192262947, rel. Juiz Moacir Leopoldo Haeser, j. 18.03.1993). 
Algo deve ser dito sobre o Código em vigor, que, a nosso ver, embora não tenha prevalecido esta posição no plano da jurisprudência, ${ }^{2}$ é o da enumeração taxativa dos casos de cabimento do agravo de instrumento. As hipóteses que não estão ali enumeradas deveriam ser resolvidas, a nosso ver, com o uso do mandado de segurança contra ato judicial, se preenchidos os demais pressupostos.

A doutrina sobre este tema sempre foi e é, ainda hoje, "inçada de contradições, e tem oscilado de posições que vão desde a negativa absoluta, até a mais completa liberalidade, admitindo-o [o mandado de segurança] mesmo contra coisa julgada". ${ }^{3}$ Entretanto, houve vozes autorizadíssimas que consideraram inadmissível o mandado de segurança contra ato judicial, pura e simplesmente. ${ }^{4}$

À luz do CPC de 1973, pode-se dizer que houve abuso dos advogados e a correlata tolerância excessiva da jurisprudência, que fez com que o uso do mandado de segurança contra ato judicial perdesse sua característica de absoluta excepcionalidade e passasse, de certo modo, como dissemos, a ser mal visto. Um dos desvios que se notavam na jurisprudência consistia na exigência, que sempre consideramos descabida, no sentido de que o recurso cabível contra a decisão (que normalmente era o agravo) fosse interposto simultaneamente e de que ao mandado de segurança se atribuísse a função de dar efeito suspensivo ao recurso interposto. Esse fenômeno, em nosso entender, sempre foi uma imensa distorção e sintoma evidente do abuso do emprego do mandado de segurança contra ato do juiz. ${ }^{5}$

Na verdade, o sentido e a razão de ser da utilização do mandado de segurança para impugnar ato do juiz, é a de evitar a ocorrência de um dano que o sistema recursal não está, no momento, aparelhado para evitar. Quando o sistema da lei ordinária é absolutamente inoperativo no caso concreto, e se a situação se encaixa nas exigências do dispositivo constitucional, cabe mandado de segurança contra ato do juiz.

A nosso ver, portanto, não tivesse havido os abusos que houve, o uso do mandado de segurança contra ato judicial não seria um "mal que deveria ter sido combatido".

O uso do mandado de segurança contra ato do juiz se justifica e é harmônico com o sistema quando a lei ordinária não contém medida eficaz e imediata para resguardar o direito da parte. Então, o seu campo de utilidade tem, evidentemente, variado em função do sistema recursal em vigor.

Pode-se dizer que a história do mandado de segurança contra atos do juiz passou por várias fases.

A primeira fase $^{6}$ se estendeu até a edição da Lei 1.533/51, e a discussão, até então, girava em torno de se saber se o juiz se encaixava, ou não, no conceito de autoridade, que constava da Constituição Federal. ${ }^{7}$ Com isso, deixou-se de lado a preocupação ligada ao tipo de ilegalidade que, uma vez cometida pelo juiz, daria azo à impetração do mandado de segurança.

$2 \quad$ Como se verá adiante com mais vagar.

3 Pedro Leonel Pinto de Carvalho. Segurança e recurso contra ato jurisdicional, RePro 32/315-317.

4 Luis Eulálio de Bueno Vidigal. Mandado de segurança. São Paulo: Saraiva, 1965, p. 63 e ss.; Alfredo Buzaid. Do mandado de segurança, $R F$ 164/13, 6. Esses autores só admitem o writ contra ato de natureza administrativa praticado pelo juiz.

5 A respeito do mandado de segurança contra atos judiciais antes da Reforma de 1995, cf. o que escrevemos em Mandado de segurança, medida cautelar e ato judicial. 3. ed. São Paulo: RT, 1994, passim.

6 "3 - A primeira fase, caracteriza-se pela ausência de texto legislativo que autorizasse expressamente ou expressamente vetasse a impetração de segurança contra ato jurisdicional. Silenciava a respeito a Constituição de 1934, mencionando apenas a exigência da ilegalidade ou abuso de poder, proveniente de ato de qualquer autoridade. Igualmente a Lei 191/36, que regulamentou o dispositivo constitucional, e o Código de Processo Civil, entrado em vigor no ano de 1939”. (J. J. Calmon de Passos. Mandado de segurança contra atos jurisdicionais: tentativa de sistematização nos cinqüenta anos de sua existência. RePro, São Paulo, v. 9, n. 33, p. 47-69, jan./mar. 1984, especialmente p. 49).

$7 \quad$ Saber se o juiz é, ou não, autoridade foi obstáculo já hoje absolutamente superado pela doutrina. Neste sentido, a lição de Arnoldo Wald: "Não há dúvida alguma quanto ao enquadramento dos órgãos do Poder Judiciário entre as autoridades cujos atos são susceptíveis de controle por mandado de segurança”. E prossegue, asseverando que, em face da letra dos textos constitucionais (tanto dos revogados, quanto dos então vigentes, ou seja, os arts. 141, § 24, da CF de 1946 e 153, § 21, da CF de 1969), não há como dar interpretação restritiva à lei ordinária de molde a frustrar a intenção do constituinte, que aludiu a "qualquer autoridade" (O mandado de segurança na prática judiciária. Rio de Janeiro: Forense, 1968, p. 155). No mesmo sentido a lição de Castro Nunes: "Atos judiciais são atos de autoridade, porque autoridades são os tribunais e juízes, quer no exercício da função jurisdicional, quer quando praticam atos nas suas funções administrativas” (Do mandado de segurança. 7. ed. Rio de Janeiro: Forense, 1967, p. 98). É, então, o juiz autoridade, no sentido do texto constitucional. Aliás, o texto da atual 
Isso porque, na fase anterior à lei do mandado de segurança de 1951, só havia texto de lei (a Lei 191/1936) em que se aludia a ato praticado por autoridade, e não se fazia referência expressa à possibilidade de se impetrar mandado de segurança contra ato do juiz, como constou da redação da Lei 1.533/51 (art.

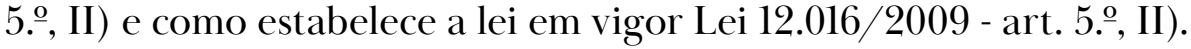

Após 1951, começou a delinear-se uma nova fase, ${ }^{8}$ em que a preocupação da doutrina e da jurisprudência voltava-se, quase que exclusivamente, a saber se havia, ou não, recurso que, em tese, fosse cabível contra o ato do juiz, com vistas a afastar a possibilidade de cabimento do mandado de segurança.

Esta exigência tinha sentido (a de que não coubesse recurso contra a decisão), pois, à luz do CPC de 1939, as hipóteses de cabimento do agravo de instrumento eram previstas de modo taxativo (art. 842, CPC de 1939). Muitas decisões ficavam, de fato, sem recurso.

Com a vigência do Código de Processo Civil de 1973, que introduziu um sistema em que de toda decisão judicial cabia recurso, é que passou, a discussão, a girar predominantemente em torno da noção de "prejuízo irreparável", embora esta preocupação já se tivesse esboçado mesmo antes da vigência do CPC/1973. Esta é a terceira fase.

Passou-se a interpretar a exigência da lei de 1951, que, literalmente, só fazia sentido à luz do CPC de 1939, como sendo a de que houvesse recurso INOPERATIVO, ou seja, INCAPAZ de OBSTAR o prejuízo (= eficácia da decisão) como requisito para o cabimento do mandado de segurança contra ato judicial.

Então, passou-se a entender a exigência da lei, não mais no sentido de que do ato judicial não poderia caber recurso, mas que, uma vez cabível recurso sem efeito suspensivo, tal recurso seria inoperante Esta era uma das hipóteses de recurso “inoperante”, mas não a única.

Quando da edição da Lei 12.016, o legislador, considerando que esse fosse o único caso (de recurso inoperante), transformou-o em lei - art. 5.., II. Entretanto, à luz do CPC de 2015, afere-se que a inoperatividade do recurso decorre de haver espaço de tempo entre a decisão e a impugnabilidade. ${ }^{9}$

O fato de ter havido "tons predominantes" nas discussões que houve nas mencionadas três fases que se seguiram, ao longo do tempo, é perfeitamente explicável. Num primeiro momento, não havia senão o texto constitucional e, em 1936, a Lei 191. Daí a pertinência da dúvida, a respeito de o juiz ser abrangido, ou não, pelo único conceito tratado pela lei: o de autoridade.

Com a edição da Lei 1.533/51, o legislador manifestou, de forma clara e inequívoca, sua intenção de tornar cabível o mandado de segurança contra atos do juiz, passando a carecer de sentido a discussão em torno de ser ele autoridade ou não, para fins do texto constitucional. Entretanto, segundo o que dispunha o art. 5.. , inc. II, daquela Lei, cabia mandado de segurança contra o ato do juiz, desde que contra tal ato não coubesse nem recurso, nem correição parcial. À luz do estatuto processual de 1939, por sua vez, cabia indagar, em primeiro lugar, se o ato era ou não recorrível e, após, se era passível de correição/ reclamação. Para que o ato fosse atacável por meio de mandado de segurança, era necessário que esse remédio fosse o único meio idôneo de se o vulnerar, ou seja, o único meio apto a evitar, em termos práticos, o prejuízo da parte.

Em face do sistema recursal do Código de Processo Civil de 1939, fazia sentido imporem-se estas restrições, pois, como se viu, nem todas as decisões proferidas no curso do feito eram recorríveis. Abraçava, aquele estatuto, o princípio da relevância das decisões recorríveis. Daí, fundamentalmente, a preocupação que dominou a segunda fase de que aqui tratamos.

Constituição não deixa margem à menor sombra de dúvida quanto a este aspecto, pois que coloca lado a lado a autoridade pública e o agente de pessoa jurídica, que tenha agido no exercício de funções de caráter público.

8 "4 - A segunda fase tem por marca significativa, inversamente, a existência de previsão expressa do legislador a respeito da admissibilidade do writ contra ato jurisdicional. A Lei 1.533, em seu art. 5.. , cuidando da inadmissibilidade do mandado de segurança, colocava, em seu inc. II, a do despacho ou decisão judicial, havendo recurso previsto nas leis processuais ou sendo possível modifica-lo por via de correição.

Destarte, a contrário senso, entendeu-se que a inadmissibilidade nas situações indicadas significava sua admissibilidade em circunstâncias diversas. Em princípio, portanto, uma perda de força dos radicais, contrários a sua admissibilidade, ainda quando nenhum deles haja recuado em seus pontos de vista teóricos. Mas os tribunais, de modo quase definitivo, abandonaram a tese da inadmissibilidade”. (J. J. Calmon de Passos. Op. cit., p. 49). 
Com o advento do Código de Processo Civil de 1973, frisemos, inaugurou-se a terceira fase $:^{10}$ o recurso de agravo de instrumento (ou retido) passou a ser cabível de toda decisão proferida durante o processo e, ainda, segundo pensamos, de todos os pronunciamentos judiciais que fossem capazes de gerar prejuízo, ainda que, eventualmente, não pudessem, rigorosamente, ser encartados na categoria das decisões interlocutórias.

Passou a carecer de sentido, então, em face do CPC de 1973, indagar se contra o ato judicial, cabia, ou não, recurso. Os únicos atos do juiz contra os quais não cabia recurso eram, em princípio, os despachos de mero expediente, que, porque desprovidos de conteúdo decisório, eram (e são) inaptos a gerar prejuízo. ${ }^{11}$ Estes pronunciamentos, pois, se não são nem recorríveis, certamente não dão azo à impetração do mandado de segurança, que supõe se esteja diante de um ato ilegal e que ofenda direito líquido e certo.

Toda a problemática, nesta terceira fase, passou a ser enfocada, a partir da ideia de que o ato do juiz, para que pudesse ser atingido pela via do mandado de segurança, deveria ser apto a gerar prejuizo/ lesão de difícil ou impossível reparação. Assim, embora do ato pudesse caber recurso, este seria inapto a impedir o prejuízo da parte. ${ }^{12}$

Por isso, justamente, é que afirma, Calmon de Passos, que a ênfase dada a estes pontos, que variaram nessas três "fases" que se seguiram, impediu que se traçassem regras científicas, capazes de orientar o advogado e os juízes, quanto ao cabimento do mandado de segurança contra ato judicial, pois que, para que fossem traçadas essas diretrizes, não se podia prescindir dos demais elementos, que deveriam, também, ser levados em conta. Essas facetas, às quais se deu atenção em épocas passadas, como se nelas estivessem embutidas soluções, não eram as únicas e o seu exame isolado não poderia ter levado, como de fato não levou, à conclusão alguma..$^{13}$

Com a Reforma do CPC de 1973, que ocorreu em 1995, passou-se a poder falar na existência de uma quarta fase.

Na terceira fase, a discussão girou, predominantemente, em torno de saber se o ato do juiz era capaz de, se eficaz, gerar prejuízo irreparável à parte. Evidentemente, este quadro só se delineava concretamente quando o ato era impugnável por meio de um recurso que fosse desprovido de efeito suspensivo! O efeito suspensivo, obstando a que a decisão produzisse efeitos, fazia com que não chegasse, a situação, a preencher os requisitos de natureza constitucional: a decisão que não tivesse produzido efeitos, rigorosamente, não teria, ainda, ofendido direito líquido e certo da parte.

A quarta fase, pode-se dizer, refere-se ao período em que estava em vigor o CPC de 1973, reformado em 1995, tendo sido ampliadas as hipóteses em que ao agravo se podia dar efeito suspensivo, formulando-se este pedido no bojo do próprio agravo.

Mas, em 2009 entrou em vigor a Lei 12.016 que transformou em direito positivo a construção doutrinária concebida à luz da versão inicial do CPC de 1973. Não cremos que teria inaugurado uma fase diferente.

10 "5-A terceira fase caracteriza-se pelo abandono, de parte do STF, da posição restritiva, alargando-se a admissibilidade do writ, já agora entendido colmo admissível desde que desprovido o recurso de efeito suspensivo e incapaz a correição de obstar a ilegalidade, reclamando-se mais a existência de dano efetiva e objetivamente irreparável, decorrente de ilegalidade patente e manifesta do ato impugnado (RTJ 72/743).

Em relação ao passado, ela inova, trazendo à baila o problema do dano irreparável, exigido como necessário para deferimento da segurança; sem ele, mesmo havendo ilegalidade, desacolhe-se o writ”. (J. J. Calmon de Passos. Op. cit., p. 50).

11 A regra do $\$ 4 .^{\circ}$ do art. 203 do CPC/15 é um dispositivo de caráter genérico em que se estabelece que atos "meramente ordinatórios” devem ser praticados ex officio pelo servidor e revistos pelo juiz, quando necessário for. Esses atos seriam, por exemplo, a juntada de um rol de testemunhas ou a vista obrigatória. $\mathrm{O}$ art. $203, \S 4 .^{\circ}$ diz que ficam a cargo do serventuário da justiça, atos meramente ordinatórios, que, agora, independem de despacho. Estes atos que devem ser praticados de ofício pelo serventuário da justiça, equivalem aos pronunciamentos que consistiam no conteúdo dos despachos de mero expediente.

12 Porque desprovido de efeito suspensivo.

13 J.J. Calmon de Passos. Op. cit., p. 51. 
A opção do legislador processual civil de 2015, entretanto, abriu, novamente, espaço para a utilização do mandado de segurança contra atos do juiz, já que muitos deles estariam sujeitos à recorribilidade por um recurso incapaz de evitar o prejuizo da parte. A nosso ver, deveria ter sido inaugurada uma quinta fase.

O ato que é impugnável, apenas quando e se houver outra decisão, através do recurso que desta outra decisão vier a caber, pode, sim, em tese, gerar prejuízo (= ofender direito líquido e certo) que não pode ser obstado pelo próprio recurso! É o caso das interlocutórias não agraváveis.

Em suma, o cabimento do mandado de segurança contra atos judiciais só pode ser estudado, compreendido e regrado se se considerar:

a) o texto constitucional vigente;

b) o texto que disciplina o mandado de segurança; e

c) o sistema recursal criado pelo Código de Processo Civil que esteja em vigor.

O exame desses textos é que nos fornece os parâmetros para que se possa estabelecer quando se pode admitir o mandado de segurança contra ato do juiz.

A esse propósito, são oportunas as palavras de Arruda Alvim ao dizer que o cabimento do mandado de segurança contra ato judicial justifica-se, principalmente, se se encara o direito positivo como um todo, que tem seu funcionamento regrado, às vezes mais de perto, às vezes à distância, mas sempre, em última análise, pela supremacia do direito constitucional. Este enfoque é bem explorado por Arruda Alvim. ${ }^{14}$

De acordo com o art. 5º, LXIX, da Constituição Federal, "conceder-se-á mandado de segurança para proteger direito líquido e certo, não amparado por habeas corpus ou habeas data, quando o responsável pela ilegalidade ou abuso de poder for autoridade pública ou agente de pessoa jurídica no exercício de atribuições do Poder Público.” A própria lei em vigor faz referência a esta possibilidade.

Vejamos: todo ato que ofende direito líquido e certo é ilegal, embora a recíproca não seja verdadeira.

Por outro lado, o ato abusivo também é ilegal, pois a ilicitude, como mau uso do poder discricionário, é redutível à ilegalidade.

No texto da Constituição se tem feito e se faz esta distinção, embora seja rigorosamente desnecessária, porque, como se sabe, o campo próprio de atuação do mandado de segurança, e em função de que foi concebido, é o dos atos administrativos. Estes atos são, tradicionalmente, passíveis de serem encartados em dois grandes grupos: o dos atos vinculados e o dos atos discricionários. E a ilegalidade está para o ato vinculado assim como a circunstância de ser abusivo está para o ato discricionário, e ambos podem ser vistos, a ilegalidade e o abuso, como o seu "avesso".

O segundo parâmetro, já referido, é a Lei 12.016/2009:

"Art. 5ํㅜ Não se concederá mandado de segurança quando se tratar:

I - de ato do qual caiba recurso administrativo com efeito suspensivo, independentemente de caução;

II - de decisão judicial da qual caiba recurso com efeito suspensivo;

III - de decisão judicial transitada em julgado”.

Vê-se, aqui, com clareza, que o legislador transformou em direito posto a hipótese em que o recurso era inoperativo, à luz do CPC de 1973: quando carecia de efeito suspensivo.

Todavia, o CPC de 2015 traz outra hipótese de inoperatividade do recurso, para efeito de evitar o prejuízo da parte: a da interposição tardia do recurso, depois que a decisão já terá produzido seus efeitos.

$14 \quad$ Notas a respeito dos aspectos gerais e fundamentais da existência dos recursos - Direito brasileiro. RePro $48 / 7-26$. 
Novamente, a lei tem que ser interpretada, de molde a que tenhamos que nos afastar da dicção literal do art. 5.-, II, que era adequada ao CPC de 1973, mas não o é ao CPC de 2015. O cerne do problema é a INOPERATIVIDADE do recurso, o que ocorre, evidentemente, com sua interposição tardia (art. $\left.1.009, \S 1 .{ }^{\circ}\right) .^{15}$

A admissibilidade da impetração do mandado de segurança contra ato judicial é fruto de uma construção, predominantemente, jurisprudencial, mas também doutrinária, que sempre teve por escopo, fundamentalmente, dar solução a situação de decisões interlocutórias, não impugnáveis por recurso ou impugnáveis por recurso inoperativo, que afrontavam a lei e que fossem capazes de gerar prejuizo irreparável ou de dificil reparabilidade.

Não se pode, pois, fazer com que o uso do mandado de segurança contra o ato do juiz acabe por tornar inútil o sistema de recursos do Código de Processo Civil. Por isso, seu uso, quando impetrado contra ato judicial, não pode ser indiscriminado. Não pode ser empregado, o mandado de segurança, quando visa a vulnerar ato do juiz no lugar do recurso, pura e simplesmente.

Por isso é que dizia Carlos Mário Velloso ${ }^{16}$ que a tendência absolutamente generalizada é a de "admitir a segurança contra decisões judiciais em geral, observadas, todavia, certas condições". A mais importante delas é a potencialidade de o ato atacado gerar o que a doutrina e a jurisprudência têm chamado de dano irreparável. Esta era e é a característica que, segundo se vinha entendendo, destacava, dentre as decisões judiciais, aquelas que podiam ser atacadas pelo mandado de segurança.

Trata-se de uma expressão de impossível apreensão plena, que não comporta, ipso facto, definição ou conceituação. É o que a doutrina denomina de conceito ou expressão vaga.

Em que consiste, em última análise, essa irreparabilidade? Esse prejuízo grave? Esse dano de difícil ou impossível reparabilidade?

O dano irreparável existe quando concreta, fática e palpavelmente (no plano real) for de difícil reparação o prejuízo ocasionável pela eficácia (no sentido do resultado da efetiva produção de efeitos) da decisão impugnada, que só ocorrerá se, por algum motivo, os efeitos da decisão não puderem ser ou não forem suspensos. Esse "algum motivo" pode ser ausência de efeito suspensivo, ou, como é à luz do CPC de 2015, o fato de se diferir no tempo a possibilidade de a parte ver a decisão, que lhe causa prejuízo, reformada (art. 1.009, § 1. $.^{\mathrm{o}} .^{17}$

Evidentemente, a perspectiva de que o ato impugnado gere prejuízo irreparável, como condição para que se o possa atacar pela via do mandado de segurança, se coloca como um plus, ou seja, além dos outros requisitos básicos que são os de o ato ser:

a) ilegal; e

b) violar direito líquido e certo.

É um requisito específico que autoriza a parte a lançar mão de um remédio de caráter excepcional, quando usado no contexto dos atos do juiz. Os meios postos à disposição da parte, pelo CPC, devem ser insuficientes para evitar o dano.

É justamente a perspectiva da ocorrência do prejuízo irreparável que, predominantemente, faz com que as decisões judiciais se tornem, além de recorríveis, passíveis de serem atingidas pela via do mandado de segurança. É o caso, justamente, de muitas das decisões que só podem ser impugnadas nas razões ou nas contrarrazões de apelação.

15 Em sentido semelhante: Clayton Maranhão. Agravo de instrumento no Código de Processo Civil de 2015: entre a taxatividade do rol e um indesejado retorno do mandado de segurança contra ato judicial. RePro, São Paulo, v. 256/2016, p. 147-168. RTOnline, p. 16.

16 Direito líquido e certo e decadência. In: Sergio Ferraz (org.). Mandado de segurança. Porto Alegre: Fabris /IAB, 1986, p. 61 (g.n.).

17 Tratando das interlocutórias não agraváveis: "É natural que não se deve admitir o mandado de segurança como um simples sucedâneo do agravo de instrumento naquelas hipóteses de seu não cabimento em razão do rol legal previsto no art. 1.015 do Novo CPC. Por outro lado, entendo que fechar as portas ao mandado de segurança como forma de impugnação a tais decisões também não é o melhor entendimento, ainda que esta venha a ser a posição adotada pelos tribunais.” (Daniel Amorim Assumpção Neves. Ações constitucionais. 3. ed. Salvador: Juspodivm, 2017, p. 159). 
Sobre a utilização do mandado de segurança no ambiente dos recursos, manifestava-se Carlos Alberto de Salles, à luz do CPC de 1973, corretamente, que, "ao revés de significar um mal em si, o mandado de segurança contra atos judiciais, medida, de fato, freqüente em data anterior à primeira reforma da disciplina do agravo, ${ }^{18}$ demonstra a capacidade de nossa doutrina e jurisprudência responderem a problemas não perfeitamente equacionados dentro das normas ordinárias do sistema jurisdicional. O retrospecto da matéria, indicando uma freqüente utilização do mandado de segurança como medida (de caráter cautelar) complementar a recursos, não pode ser visto como uma deturpação. (...) Errada não era a utilização do mandado de segurança naquelas situações. Errado estava o sistema processual ao não oferecer alternativa capaz de propiciar uma efetiva proteção ao interesse das partes". ${ }^{19}$

Parece-nos correta a opinião do autor citado. Com efeito, a impetração de mandado de segurança contra atos judiciais não devia - e não deve - ser considerada medida juridicamente "errada"; "errado" foi o uso excessivo e deturpado de tal medida, que não foi refreado - ao contrário, foi incentivado pela jurisprudência. Já se admitiu, acertadamente, o manejo do mandado de segurança contra decisões recorríveis nas hipóteses de decisão teratológica ${ }^{20}$, manifestamente ilegal ${ }^{21}$ ou proferida com abuso de poder, desde que haja potencialidade para gerar dano grave ou de difícil reparação.

Com efeito, o uso do mandado de segurança para suspender os efeitos da decisão agravada, como se fazia, à luz do CPC de 1973, por muito tempo, transformava o remédio constitucional em mera medida cautelar. Com as Reformas, substituiu-se o uso excessivo do mandado de segurança pelo uso excessivo dos agravos de instrumento, e este último em muito maior escala.

Com o novo CPC, na nossa opinião, o ideal seria ter-se deixado as situações em que as decisões interlocutórias do juiz de 1. grau não podem ser imediatamente impugnadas pela via recursal, para o campo da impugnação pelo mandado de segurança, em situações excepcionais. ${ }^{22}$

Afirmava, com razão, à luz do CPC de 1973, Carlos Alberto de Salles: "Espera-se, no entanto, que a diminuição no uso [do mandado de segurança] não sirva para levar ao esquecimento do importante corpo doutrinário e jurisprudencial construído acerca da matéria”. ${ }^{23}$

É relevante, por fim, consignar-se, aqui, que, sob o regime atual, nos acórdãos que julgaram o REsp 1.696.396/MT e o REsp 1.704.520/MT, afetados para serem paradigmas no regime dos repetitivos, observou-se, de passagem, i.e., como força apenas de obter dictum, que seria incabível o mandado de segurança para impugnar as decisões que, embora não alistadas no art. 1.015, possam ser impugnadas, imediatamente.

No contexto, faz sentido. Se corretas as premissas, haveria mesmo de ser esta a solução, já que o próprio CPC, se interpretado como foi pelos mencionados acórdãos do STJ, seria capaz de oferecer solução para que se obstasse eventual dano produzido pela não impugnabilidade imediata da decisão.

18 Refere-se o autor à Reforma de 1995.

19 Mandado de segurança contra atos judiciais. In: Teresa Arruda Alvim Wambier; Eduardo Arruda Alvim; Cassio Scarpinella Bueno (coords.). Aspectos polêmicos e atuais do mandado de segurança - 51 anos depois. São Paulo: RT, 2002 , p. 124.

20 STJ, RMS 52.238/SP, rel. Min. Nancy Andrighi, 3ㅜㅜ T., j. 15.12.2016; AgRg no AREsp 89.048/SP, rel. Antonio Carlos Ferreira, $4^{\mathrm{a}}$ T., j. 08.03.2016.

21 STJ, RMS 61.308/MG, 1ª T., rel. Min. Sérgio Kukina, j. 05.11.2019.

22 "Assim, tendo em vista que o meio próprio para atacar decisões judiciais é o recurso, é preciso que exista uma qualidade específica de que deveria estar revestida a ofensa ao direito do lesado, para que tais decisões pudessem ser atacadas por mandado de segurança. Essa qualidade específica é o risco, a potencialidade de dano irreparável.” (Arlete Inês Aurelli. Impactos no novo CPC sobre o mandado de segurança. In: Paulo Henrique dos Santos Lucon (coord. et. al.). Processo em jornadas. Salvador: Juspodivm, 2016, p. 121). No mesmo sentido: "Dessa forma, tendo em vista a recorribilidade das interlocutórias não agraváveis, o mandado de segurança somente será cabível quando a decisão causar à parte lesão irreparável ou de difícil reparação, de modo que não se pode aguardar até a fase recursal (apelação ou contrarrazões de apelação) para impugná-la, sob pena de prejuízos incomensuráveis ao direito material ou ao processo.” (Pablo Freire Romão. Taxatividade do rol do art. 1.015, do NCPC: mandado de segurança como sucedâneo do agravo de instrumento? RePro, São Paulo, v. 259/2016, p. 259-273. RTOnline, p. 9.).

23 Carlos Alberto de Salles. Mandado de segurança contra atos judiciais. In: Teresa Arruda Alvim Wambier; Eduardo Arruda Alvim; Cassio Scarpinella Bueno (coords.). Aspectos polêmicos e atuais do mandado de segurança - 51 anos depois. São Paulo: RT, 2002, p. 124. 
Nossas conclusões, entretanto, são diferentes, já que nossas premissas não coincidem com as adotadas no acórdão.

De fato, o espaço do mandado de segurança contra atos do juizé aquele deixado pela insuficiência do sistema recursal. Se se interpreta o sistema como se ele fosse realmente operativo, sem deixar "furos" (e foi o que se fez nos acórdãos referidos), não há lugar para o mandado de segurança.

\section{2) O atual posicionamento do STJ}

$\mathrm{O}$ art. 1.015 do CPC, que enumera as hipóteses de cabimento do agravo de instrumento, a nosso ver de forma taxativa, já nasceu gerando acaloradas discussões.

O STJ afetou os dois recursos, acima referidos, para serem julgados no regime dos repetitivos e fixou uma posição, cristalizada em dois precedentes vinculantes de idêntico teor.

O critério recomendado e usado em ambos os acórdãos afetados, em que se fixou a tese da taxatividade "mitigada", para reconhecerem-se as hipóteses de cabimento do agravo que estão fora da abrangência expressa do art. 1.015 é "a urgência decorrente da inutilidade do julgamento da questão no recurso de apelação". Isto significa que os casos em que o espaço de tempo entre a decisão e a possibilidade de que esta seja impugnada e, eventualmente, reformada, criar o risco de que fique esvaziada a eficácia do provimento do recurso, serão casos de cabimento do agravo.

O enunciado teórico do pressuposto para identificar os casos em que a decisão seria agravável, fora dos casos do art. 1.015, açambarca casos como, por exemplo, o da necessidade de oitiva de uma testemunha doente e idosa. Depois do falecimento desta, a reforma da decisão é de evidente inutilidade. A verdade é que o enunciado teórico constante do acórdão corresponde ao periculum in mora, tratado em profundidade pelos autores clássicos que escreveram sobre as "medidas cautelares". ${ }^{24}$

Deu-se provimento ao recurso especial, em ambos os casos, para se determinar que os agravos interpostos de decisão que versava sobre competência fossem julgados.

Nestes primorosíssimos acórdãos, de que consta minuciosa análise das posições existentes na doutrina, além de reflexões oportunas e interessantes sobre o caminho percorrido pelo agravo, ao longo da história do direito, fugiu-se da discussão sobre se a válvula de escape à pretensa taxatividade seria a interposição extensiva e/ou analógica.

Elegeu-se, isto sim, um critério para identificar as situações que ensejam a impugnabilidade pela via do agravo de instrumento, sem vinculá-lo a nenhum dos incisos do art. 1.015 do CPC.

Reconheceu-se, portanto, a necessidade de limitação das decisões agraváveis como tendo sido sentida pelo legislador.

No entanto, afirma-se, no acórdão, que um rol taxativo é solução que se tem revelado inoperativa ao longo da história do processo civil: "Ocorre que o estudo da história do direito também revela que um rol que pretende ser taxativo raramente enuncia todas as hipóteses vinculadas a sua razão de existir, pois a realidade normalmente supera a ficção e a concretude torna letra morta o exercício de abstração inicialmente realizado pelo legislador".

De fato, "a realidade sempre suplanta a ficção". ${ }^{25}$

A inutilidade da reforma posterior da decisão ocorre, e aqui damos mais um exemplo, em caso de pedido indeferido no sentido de que o processo tramite em segredo de justiça. A intimidade das partes já terá sido exposta, quando do julgamento da apelação, que, ainda que promova a reforma da decisão, se revelará inútil. Este exemplo é mencionado no acórdão: esta situação diz-se com absoluto acerto no acórdão, não seria resolvida nem com a interpretação analógica nem com a interpretação extensiva!

24 A respeito, v.: Galeno Lacerda. Comentários ao Código de Processo Civil. V. VIII, t. I. 3. ed. Rio de Janeiro: Forense, 1987; Humberto Theodoro Jr.. Processo cautelar. São Paulo: Leud, 1983; Ovídio A. Baptista da Silva. Do processo cautelar. 3. ed. Rio de Janeiro: Forense, 2006; Athos Gusmão Carneiro. Da antecipação de tutela. 7. ed. Rio de Janeiro: Forense, 2010. 
Mas esta urgência, a nosso ver, não ocorre justamente no caso de decisão sobre competência.

Em nossa opinião, nas hipóteses alistadas pelo art. 1.015, o legislador quis assumir um risco: em muitos casos, se no julgamento da apelação, se reformar a interlocutória lá impugnada, o PROCESSO TERÁ QUE VOLTAR ATRÁS. É o que decorre, por exemplo, do não cabimento de recurso de decisão que indefere pedido de produção de prova. Reformada a decisão, no julgamento da apelação, pela regra de SUBSTITUTIVIDADE, tudo volta atrás e o juízo de 1.o grau deverá proferir outra sentença com base na prova então produzida.

Fenômeno semelhante acontece com decisões acerca de matéria de ordem pública. Decidindo o juiz no sentido de que as partes são legítimas e sendo essa decisão impugnada, na apelação, se o resultado for a reforma da decisão, toda a atividade do 1. grau (produção de provas, contraditório etc.) terá sido inútil.

Essas hipóteses, a nosso ver, não estão abrangidas pela: provável inutilidade do provimento do recurso, nem pela possível inutilidade da apreciação posterior da questão. Não haverá, propriamente, INUTILIDADE. A nosso ver, e insistimos aqui neste ponto, foi um risco que o legislador decidiu correr.

Entendemos que a hipótese de competência está abrangida pela racionalidade desta opção do legislador, que parte de uma atitude de confiança em relação ao 1.ํ grau de jurisdição. Assim como era fruto dessa atitude a regra no sentido de se retirar da apelação o efeito suspensivo, que chegou a constar do projeto do CPC de 2015, durante uma das fases de sua tramitação, nas casas legislativas, também por meio da taxatividade do rol do art. 1.015, quis o legislador prestigiar o juízo de 1. grau.

Na verdade, se reformada a decisão que diz respeito à competência, nasce uma "situação jurídica de difícil ou de impossível restabelecimento futuro” (p. 44 do acórdão) o que, a nosso ver, não se confunde com a inutilidade do provimento do recurso. Até porque, atos do juízo incompetente devem ser, o quanto possível, aproveitados. ${ }^{26}$

Haverá, sim, desperdício de tempo. Mas este desperdício é, como dissemos, em nossa opinião, fruto de um risco assumido pelo legislador, ao limitar as hipóteses de decisões imediatamente impugnáveis pela via do agravo de instrumento. ${ }^{27}$

O debate surgido em torno da decisão do STJ acordou discussão antiga entre os limites da atividade interpretativa. Os limites semânticos contidos no texto - o significado das palavras - é um dos óbices mais relevantes para balizar a atividade interpretativa. O sentido das palavras constantes da lei não deve ser desprezado pelo intérprete. A existência de significados mínimos incorporados pela lei são um limite para o intérprete. ${ }^{28}$

Em interessante texto, com cuja conclusão não concordamos, Arthur Thompsen Carpes observa, acertadamente, que ignorar o sentido das palavras constantes da lei é desprezar o papel confiado ao legislador no processo de criação do direito.

26 A respeito, vide: Priscila Kei Sato. Translatio iudicii no direito processual civil brasileiro. Tese de Doutorado. Pontifícia Universidade Católica de São Paulo, 2010. Sobre o mesmo tema, escrevemos com Priscila Kei Sato: "No Brasil, o princípio da translatio iudicii e a reassunção do processo fazem parte do sistema processual civil, sem que essas denominações sejam expressamente adotadas. Trata-se da reassunção do processo e remessa dos autos ao juízo competente, nos casos em que é declarada a incompetência relativa. Nessa hipótese, há o aproveitamento de todos os atos (inclusive decisórios), conservandose seus efeitos materiais e processuais". (Teresa Arruda Alvim Wambier; Priscila Kei Sato. O princípio da translatio iudicii e a competência das Justiças Federal e Estadual. In: José Roberto d'Affonseca Gusmão (org.). Temas de propriedade intelectual: 25 anos de Gusmão Ẽ Labrunie. São Paulo: Gusmão \& Labrunie Advogados, 2013, p. 465-506, especialmente p. 479).

$27 \quad$ Neste sentido, manifesta-se Henrique de Moraes Fleury da Rocha: "Em quarto lugar porque, apesar de possivelmente significar atraso à prestação da tutela jurisdicional, não se afigura necessariamente inútil a suscitação da incompetência do juízo apenas após a prolação da sentença. É o que ocorre, por exemplo, nos casos de incompetência relativa, em que bastará ao Tribunal determinar a remessa dos autos ao juízo competente para sanar o vício, ainda que tardiamente. Entretanto, naquelas hipóteses em que for verdadeiramente inócua (ou impossível) a impugnação da decisão interlocutória somente em preliminar de apelação ou nas contrarrazões, será admitida a impetração de mandado de segurança, tendo em vista a situação de irrecorribilidade prática da decisão". (Cabimento do agravo de instrumento segundo o Código de Processo Civil brasileiro de 2015: aspectos polêmicos. RePro, São Paulo, v. 282, p. 299-317, ago./2018. RTOnline, p. 5).

28 Arthur Thompsen Carpes. A taxatividade mitigada do art. 1.015 do CPC: notas sobre a ratio decidendi fixada no STJ na perspectiva da teoria das normas. RePro, São Paulo, v. 294, p. 227-247, ago./2019. 
É um critério interessante, embora não inteiramente seguro, já que pode haver discordância até mesmo quanto ao conteúdo mínimo de significado dos termos constantes do texto de lei. Mas é relevante, apesar de envolver dificuldades.

Há, em nosso entender, como adiantamos antes, no sistema, uma válvula de escape, que cria um caminho para a impugnabilidade das interlocutórias não abrangidas pelo art. 1.015, que são capazes de gerar prejuízo para a parte, de molde a não poderem aguardar o julgamento da apelação para serem reformadas, consistente, justamente, no mandado de segurança contra atos do juiz. A Constituição Federal o permite e a Lei Ordinária (art. 5.․, II) faz referência expressa à possibilidade de se impugnar ato judicial por meio do mandado de segurança.

Logo, o argumento consiste na inconstitucionalidade de se deixar à margem da impugnabilidade decisão que pode causar prejuízo à parte, pois que sujeito a recurso diferido e, portanto, incapaz de obstar o prejuízo, não tem respaldo no ordenamento jurídico positivo. Isto porque não há impugnabilidade absoluta: não cabe recurso, mas cabe mandado de segurança.

Portanto, nem mesmo a atividade interpretativa cujo escopo seria compreender o art. 1.015 à luz da Constituição Federal poderia, a nosso ver, levar ao alargamento do rol das hipóteses do art. 1.015. ${ }^{29}$

Outras hipóteses podem ser incluídas dentre aquelas que ensejam o cabimento do agravo se encartáveis no art. 1.015, parágrafo único, este sim meramente exemplificativo.

A hipótese de suspensão do processo é encartável, em nossa opinião, no art. 1.015, parágrafo único: lá estão, exemplificamente, as hipóteses que ensejam o cabimento do agravo de instrumento porque não haveria apelação. Neste caso, se a decisão for mantida, não será nem mesmo proferida a sentença. ${ }^{30}$

$\mathrm{O}$ art. 1.015 e seus incisos comportam interpretação extensiva, mas não analógica.

A nosso ver, em opinião já adiantada, a interpretação extensiva é bem-vinda e, de rigor, imprescindível: quando, por exemplo, se diz que cabe agravo de decisão que versa sobre tutela provisória, se diz, também, - ampliando o NÚCLEO de significado da expressão tutela provisória -, que se pode, por exemplo, recorrer das multas e de sua periodicidade. Este exemplo, a nosso ver, basta para evidenciar ser imprescindível o recurso à interpretação extensiva para interpretar os incisos do art. 1.015. ${ }^{31}$

Não se pode, todavia, interpretar analogicamente dispositivo que tenha rol taxativo de hipóteses, já que a analogia - aplicar a lei a um caso semelhante àquele expressamente disciplinado - compromete a taxatividade. ${ }^{32}$

$29 \quad$ Não conclui neste sentido o autor do texto antes citado.

30 Em sentido semelhante, encontrando a mesma solução, Henrique de Moraes Fleury da Rocha: "Nessas circunstâncias, plenamente possível o emprego da interpretação extensiva, especificamente do art. 1.037, § 13, I, do CPC/2015 - segundo o qual caberá agravo de instrumento contra a decisão interlocutória que resolver o pedido de prosseguimento de processo suspenso em razão da afetação de recurso repetitivo -, para abarcar qualquer decisão que versar sobre suspensão do processo.

Afinal, a decisão interlocutória que opta por manter suspenso o processo ou permitir o seu prosseguimento não passa de uma decisão que versa sobre suspensão. Indeferido o pedido de prosseguimento, por se entender ser o caso de suspensão, caberá agravo de instrumento. Acolhido o pedido, por se considerar equivocada a suspensão anteriormente determinada, a decisão também desafiará o agravo". (Op. cit., p.6).

31 Carlos Frederico Bastos Pereira entende, com razão, que: "Já a interpretação extensiva é uma técnica de decisão pela qual o intérprete define os contornos semânticos do texto legal para que o caso que, à primeira vista, não era regulado pelo dispositivo legal, passe a estar coberto por ele. Na interpretação extensiva, portanto, o intérprete entende que a hipótese normativa está prevista em algum dispositivo legal do ordenamento jurídico, mas que o sentido do texto não lhe abrange primo ictu oculi, tornando necessária a reconstrução dos significados textuais para definir-lhe o alcance.

$\mathrm{Na}$ interpretação extensiva, à luz da estrutura da norma jurídica (Se $p$, então $q$ ), o intérprete entende que a lei previu a hipótese normativa $(=p)$, havendo, portanto, uma consequência jurídica para o caso $(=q)$. Porém, os termos que compõem a hipótese normativa possuem problemas de indeterminação, notadamente aqueles ligados à vagueza inerente à linguagem, isto é, 'não se sabe exatamente quais os casos que entram em seu campo de aplicação'”. (Interpretação extensiva, analogia e o rol do artigo 1.015 do Código de Processo Civil. RePro, São Paulo, v. 282, p. 267-284, ago./2018).

32 Neste sentido, Carlos Frederico Bastos Pereira: "A analogia é uma técnica de decisão pela qual o intérprete transfere a consequência jurídica de um caso regulado pelo ordenamento jurídico para outro caso não regulado, graças à semelhança entre elementos relevantes que existem em cada qual. 
O critério eleito no acórdão para viabilizar a imediata impugnabilidade da decisão é, de fato, harmônico com a Constituição Federal. O critério é: a inutilidade da reforma da decisão, se esta reforma não puder ser imediata (ou resultado da impugnação imediata).

Entretanto, em nosso sentir: o caso concreto julgado (competência) não se encaixa no enunciado teórico. Não haverá inutilidade, no sentido próprio da expressão.

\section{3) Precedentes vinculantes "à brasileira"}

Nos últimos tempos, tem-se dado a devida atenção à carga normativa da jurisprudência. Tem-se reconhecido que decisões judiciais são mais do que fonte do direito: são o próprio direito. ${ }^{33-}$

O CPC de 2015 caracteriza-se, fundamentalmente, por ser um código que encampou essa tendência, valorizando a jurisprudência, a ponto de chegar a reconhecer que os Tribunais exercem papel relevante na criação do direito, tendo as decisões judiciais, em determinadas circunstâncias, poder normativo por força da própria lei.

Se são o próprio direito, é natural que se reconheça que, além de resolver a controvérsia entre A e B, decisões judiciais, em diferentes medidas, significam algo para o sistema normativo.

O direito feito pelos juízes, ou, como dizem os alemães, o Richterrecht, identifica-se com as decisões dos Tribunais que constroem a evolução do direito legislado e devem servir de base a outras decisões. ${ }^{34}$

É natural que os órgãos de 2.․o grau e os juízes singulares se curvem à posição tomada por Tribunais Superiores. Afinal, constitucionalmente, esta é a função que lhes foi atribuída. ${ }^{35}$

Analisando a analogia à luz da estrutura da norma jurídica (Se $p$, então $q$ ), nota-se que o intérprete entende que a lei não previu a hipótese normativa $(=p)$, porém, se tivesse previsto, imporia a mesma consequência jurídica de outro dispositivo legal $(=q)$, diante das similitudes entre as características essenciais das duas situações de fato.

Esquematicamente, é possível descrever o raciocínio analógico da seguinte maneira: no caso X, não existe dispositivo legal aplicável; no caso Y, aplica-se o dispositivo legal W com a consequência jurídica R; o caso X possui as características 1, 2 e 3; o caso Y possui as características 1, 2, 3 e 4; diante da semelhança entre os elementos 1, 2 e 3 dos casos X e Y, a consequência jurídica R do dispositivo legal W pode ser aplicada ao caso X.”. (Op. cit., p. 3).

33 Rebatendo o argumento de que admitir-se que o Judiciário crie direito seria transformá-lo em legislador, ofendendo a regra da tripartição de poderes, Luis Roberto Barroso e Patrícia Perrone explicam que: “Afirma-se, igualmente, que as decisões aditivas e substitutivas correspondem à produção de norma geral pelo Judiciário, equiparável a uma lei. Ainda que a parte ablativa da decisão pudesse configurar mera atuação como legislador negativo, amplamente aceita pela doutrina, a parte reconstrutiva de tais decisões, que adiciona ou substitui conteúdos, configuraria inequívoca atuação como legislador positivo. Haveria, nesse caso, usurpação dos poderes do Legislativo, violação ao princípio da separação dos poderes e ao princípio da legalidade.

Esses argumentos são rebatidos pela alegação de que, ainda que o Judiciário inove ao proferir decisões manipulativas, o conteúdo decorrente da componente reconstrutiva da decisão deve sempre equivaler à única solução constitucional possível. O juiz não produz um ato puro de vontade, tal como faria o legislador, mas explicita uma solução que já estava imanente no sistema. Essa atuação se dá dentro dos limites do exercício da jurisdição: depende de provocação por aqueles que detenham legitimidade para tal, tem por limite os termos em que a demanda é formulada e seu alcance e segue um processo em que se observam contraditório, ampla defesa e devido processo legal. A decisão deve ser fundamentada e, ao se desincumbir de tal fundamentação, o magistrado tem um ônus reforçado de demonstrar a existência de uma resposta obrigatória à luz da constituição. A constituição, a seu turno, também é lei, inclusive de hierarquia superior, razão pela qual uma decisão proferida com base nela não pode ser considerada, tampouco, como violadora do princípio da legalidade.

Por outro lado, argumenta-se, o juiz, uma vez provocado, e diante de uma violação constitucional, ainda que por omissão, não pode pronunciar um non liquet" (Luís Roberto Barroso; Patrícia Perrone Campos Mello. O papel criativo dos Tribunais. In: Aluisio Gonçalves de Castro Mendes; Cândido Rangel Dinamarco; Humberto Dalla Bernardina de Pinho; Luiz Fux (Coord.). Estudos de Direito Processual em homenagem a Paulo Cézar Pinheiro Carneiro. Rio de Janeiro: GZ Editora, 2019. p. 722).

34 Ensina Verena Klappstein: "Richterrecht sind die von den Gerichten in Fortbildung des geltenden Gesetzesrechts entwickeln und als Entscheidungsgrundlag verwenden Rechtssätze“. (Verena Klappstein. Schriften zur Rechstheorie Heft 243, Die Rechtsprechungänderung mit Wirkung fur die Zukunft. Berlin: Duncker \& Humblot, 2008, p. 39).

35 Diz Antonio do Passo Cabral: "Por outro lado, as instâncias superiores são aquelas cujos acórdãos estão mais aptos a gerar expectativas porque são estes tribunais, sobretudo em países de formato federativo como o nosso, que têm a função de uniformização do Direito, locus onde os anseios de segurança e estabilidade são ainda maiores.

Além disso, quanto mais alta é a instância, menos estão as decisões sujeitas a alterações, até porque as alternativas recursais vão sendo reduzidas. Ademais, alguns autores apontam que a experiência prática mostra que as decisões das cortes superiores 
Decisões de Tribunais Superiores devem ser respeitadas, principalmente se são muitas no mesmo sentido: jurisprudência firme.

É evidente que, nestas condições, fica limitada a liberdade de cada juiz, individualmente considerado, de interpretar a lei. É natural e desejável.

É inegável que a força que o CPC/2015 dá aos elementos oriundos do labor do Judiciário garante a isonomia, gera previsibilidade, incrementa a segurança jurídica. Ademais, racionaliza o trabalho do Poder Judiciário, gerando mais tempo para que os juízes decidam, com vagar e de modo artesanal, os casos mais complexos. ${ }^{36}$ Dizemos elementos "oriundos do labor do Judiciário" para abranger precedentes isolados, jurisprudência consolidada e também as súmulas vinculantes ou não, que não são propriamente precedentes.

Além da carga normativa natural que caracteriza certas decisões judiciais, notadamente as dos tribunais de cúpula, e a jurisprudência consolidada num certo sentido, há, hoje, no direito brasileiro, precedentes ditos vinculantes. ${ }^{37}$

De acordo com a sistemática do CPC/2015, há decisões que já nascem como precedentes obrigatórios, no sentido forte da expressão, e que são paradigma para as decisões de processos idênticos, concomitantes ou futuros.

A obrigatoriedade será tida como forte ou qualificada quando o respeito a um precedente é exigido, sob pena do manejo de medida ou ação especialmente concebida para esse fim, a reclamação. ${ }^{38}$ São precedentes obrigatórios, no sentido forte, à luz do CPC/2015, por exemplo, as decisões proferidas em recursos repetitivos, no regime dos arts. 1.036 e ss. do CPC/2015. ${ }^{39}$

possuem também uma maior constância temporal, tendendo a serem superadas com menor frequência” (Antonio do Passo Cabral. A técnica do julgamento-alerta na mudança de jurisprudência consolidada. RePro, São Paulo, v. 38, n. 221, p.13-48, jul./2013).

36 Nesse sentido, Patrícia Perrone Campos Mello e Luís Roberto Barroso: "Três valores principais justificam a adoção de um sistema de precedentes normativos ou vinculantes: a segurança jurídica, a isonomia e a eficiência. A obrigatoriedade de observar as orientações já firmadas pelas cortes aumenta a previsibilidade do direito, torna mais determinadas as normas jurídicas e antecipa a solução que os tribunais darão a determinados conflitos. O respeito aos precedentes constitui um critério objetivo e pré-determinado de decisão que incrementa a segurança jurídica. A aplicação das mesmas soluções a casos idênticos reduz a produção de decisões conflitantes pelo Judiciário e assegura àqueles que se encontram em situação semelhante o mesmo tratamento, promovendo a isonomia.

Por fim, o respeito aos precedentes possibilita que os recursos de que dispõe o Judiciário sejam otimizados e utilizados de forma racional. Se os juízes estão obrigados a observar os entendimentos já proferidos pelos tribunais, eles não consumirão seu tempo ou os recursos materiais de que dispõem para redecidir questões já apreciadas. Consequentemente, utilizarão tais recursos na solução de questões inéditas, que ainda não receberam resposta do Judiciário e que precisam ser enfrentadas. A observância dos precedentes vinculantes pelos juízes, mesmo que não concordem com eles, reduz, ainda, o trabalho dos tribunais, que não precisam reexaminar e reformar as decisões divergentes dos entendimentos que já pacificaram.

Tal ambiente contribui para a redução do tempo de duração dos processos, desestimula demandas aventureiras e reduz a litigiosidade. Tem ainda o condão de minimizar a sobrecarga experimentada pelas cortes e a aumentar a credibilidade e legitimidade do Judiciário, que são comprometidas pela demora na entrega da prestação jurisdicional e por aquilo que a doutrina convencionou chamar de jurisprudência lotérica: a produção de decisões díspares, conferindo tratamento desigual a jurisdicionados em situações idênticas, muitas vezes até em um mesmo tribunal” (Patrícia Perrone Campos Mello; Luís Roberto Barroso. Trabalhando com uma nova lógica: a ascensão dos precedentes no direito brasileiro. Revista da AGU, Brasília, v. 15, n. 03, p. 09-52, jul.-set. 2016, especialmente p. 23-24).

37 Nesses casos, não há lugar para interpretação pessoal do juiz. Nada há de negativo nisso. A liberdade e a independência são do Judiciário e não de cada juiz, individualmente considerado. Observa Evaristo Aragão Santos: “Num regime democrático, constitucional e com instituições consolidadas, pretender que a sua interpretação pessoal prevaleça contra o entendimento consolidado da maioria, essa sim é postura que flerta com a arbitrariedade" (Evaristo Aragão Santos. Em torno do conceito e da formação do precedente judicial. In: Teresa Arruda Alvim Wambier (Coord.). Direito jurisprudencial. São Paulo: RT, 2012, p. 193).

38 "Há, no outro polo, os precedentes normativos em sentido forte, correspondentes aos julgados e entendimentos que devem ser obrigatoriamente observados pelas demais instâncias e cujo desrespeito enseja reclamação" (Patrícia Perrone Campos Mello; Luís Roberto Barroso. Trabalhando com uma nova lógica: a ascensão dos precedentes no direito brasileiro. Revista da AGU, Brasília, v. 15, n. 03, jul.-set. 2016, p. 20).

39 Ver, mais à frente, ainda neste item, decisão da Corte Especial do STJ. 
Estes precedentes vinculantes no sentido forte, no Brasil, dizem respeito, quase que exclusivamente, à questões de massa, direitos individuais homogêneos, situações absolutamente idênticas.

Escrevemos, juntamente com Rodrigo Barioni, em texto que integra a justa homenagem prestada a Ministra Nancy Andrighi, que um dos temas mais complexos na lida com precedentes consiste em identificar a ratio decidendi ou holding do precedente. Essa tarefa é essencial nos países de common law, pois a ratio decidendi é o elemento vinculante do precedente e se contrapõe ao elemento não vinculante, denominado obiter dictum.

A ratio decidendi ou holding é o núcleo da decisão judicial, do qual é extraída a regra jurídica generalizável para outros casos que tratem dos mesmos fatos essenciais. Não é algo que esteja pronto e seja definido de maneira expressa pelo tribunal, que profere a decisão que posteriormente deve ser tida como precedente, mas a regra generalizável que pode ser inferida ou construída a partir da decisão judicial. ${ }^{40}$

No direito brasileiro, talvez para se conservar fidelidade à tradição de que as decisões judiciais devem ser tomadas sempre com base num enunciado normativo, os Tribunais fixam teses, ao julgarem os recursos afetados como paradigma para os repetitivos sobrestados. Estas teses, que devem ser rentes à questão objeto do(s) recursos(s), hão de dizer respeito ÀS MESMAS QUESTÕES sobre as quais versam os demais recursos.

Nessas teses, via de regra, não se contém a ratio do recurso julgado: trata-se, isto sim, de uma hipótese de aplicação da ratio, devendo ser, esta, objeto de reflexão de juízes de casos subsequentes. Os juízes que julgarão casos, posteriormente, é que decidirão, a partir da indagação sobre qual seria a ratio que está por trás da tese, se ela deveria (ou não) ser aplicada ao caso que este tem que decidir.

O processamento dos casos repetitivos adota dinâmica própria, relativamente simples, voltada a permitir o gerenciamento dos litígios de massa. Em primeiro lugar, cabe fazer-se a seleção dos recursos representativos da controvérsia, os quais constituem o paradigma da questão jurídica a ser decidida (art. 1.036, $\S \S 1^{\circ}$, $4^{\circ}$ e $5^{\circ}$, CPC). O CPC impõe que somente sejam selecionados recursos que "contenham abrangente argumentação e discussão a respeito da questão a ser decidida” (art. 1.036, § $6^{\circ}$ ), para que a quaestio iuris esteja bem identificada e sobre ela tenha havido contraditório, sob diversas perspectivas, sem prejuízo de outros argumentos pró e contra que serão apresentados nas audiências públicas e pelos amici curiae.

Quando um recurso representativo da controvérsia é afetado para ser julgado no regime dos repetitivos, cabe ao relator identificar, com precisão, a questão a ser submetida a julgamento e poderá suspender o processamento dos processos pendentes que versem sobre a mesma questão jurídica (art. 1.037, I e II, CPC). Presume-se que a questão jurídica tratada nesses casos suspensos seja absolutamente idêntica àquela submetida à apreciação no regime de casos repetitivos. Com isso, uma vez proferida a decisão que será precedente obrigatório, será fixada a tese jurídica a ser aplicada aos casos cujos procedimentos tenham sido sobrestados, embora este sobrestamento não seja compulsório.

É imprescindível sublinhar-se que os procedimentos dos recursos repetitivos e do IRDR foram concebidos para resolver as questões jurídicas de maneira uniforme para todos aqueles que estejam na mesma situação fático-jurídica, gerando maior respeito à isonomia. Paralelamente, permitem a racionalização do trabalho, levando-se com isso à otimização da atividade do Poder Judiciário em questões de massa, normalmente atreladas a direitos individuais homogêneos. Em outras palavras, visam a regular questões jurídicas relativas a fatos idênticos.

As teses jurídicas normalmente são mais fechadas, isto é, correspondentes à interpretação de hipóteses tipificadas, de maneira a solucionar o problema do enquadramento da hipótese fática ao texto legal. Assim, por exemplo, no caso do prazo prescricional para a cobrança de taxa condominial. O processamento do caso como recurso repetitivo permitiu ao STJ fixar a seguinte tese: "Na vigência do Código Civil de 2002, é quinquenal o prazo prescricional para que o Condomínio geral ou edilício (vertical ou horizontal) exercite a pretensão de cobrança de taxa condominial ordinária ou 
extraordinária, constante em instrumento público ou particular, a contar do dia seguinte ao vencimento da prestação"

A tese jurídica, normalmente, descreve a situação fática e a regra jurídica a ela correspondente. Com isso, por causa do enquadramento da situação concreta na hipótese fática descrita na tese jurídica, o precedente será a base de todas as decisões do Judiciário em casos iguais. Verifica-se, portanto, que a tese jurídica é verdadeiro mecanismo de facilitação para o uso do precedente, porque preestabelece a tipologia fática dos casos a serem regulados de forma idêntica.

Não é tarefa fácil a elaboração das “teses” jurídicas.

Os tribunais devem ter grande cuidado com a elaboração da tese jurídica, para que não reflita aquilo que não se decidiu. Sem dúvida, situações de menor variabilidade fática são mais apropriadas para a formação de teses jurídicas do que hipóteses mais abertas. De todo modo, não se pode desprezar o risco de redações demasiadamente genéricas, que pretendam indevidamente ampliar a tese jurídica além dos fatos dos casos selecionados como representativos da controvérsia. Como registra Taís Schilling Ferraz, o julgamento de casos repetitivos não "abstrai completamente do conflito que lhe deu origem e de todas as circunstâncias consideradas relevantes para que se decidisse por um determinado caminho ao julgar" ${ }^{2}$.

A formação da tese jurídica não é - e nem pode ser - isolada e autônoma dos processos em que surgiu a questão jurídica apreciada em sede de caso repetitivo. A vinculação da questão jurídica ao caso concreto julgado é essencial, procurando limitar a uma hipótese mais concreta, ainda que vasta, da questão repetitiva. Por isso é que só se aplica a casos iguais.

No entanto, aqui permanece o problema de saber o que vincula em relação aos julgamentos produzidos em sede de recursos repetitivos: a tese jurídica ou a ratio decidendi?

A tese jurídica, como dissemos antes, é bem mais específica do que a ratio e sua ligação ao caso concreto, para cuja decisão serviu de base, é mais intima do que a da ratio, que é mais genérica e carrega em si o potencial de generalizar-se ainda mais. Quanto mais "scarnificata"43 a ratio, maior número de casos poderá abranger.

Entretanto, a nosso ver, o que vincula nos recursos repetitivos, é a tese e não a ratio.

De fato, todos os métodos de julgamento de questões de massa disciplinados pelo CPC, incidente de resolução de demandas repetitivas e recursos repetitivos, pressupõem a possibilidade de que seja suspenso o processamento de outros casos, a priori, para, depois, aplicar-se o precedente para que sejam, à luz deste, decididos.

Salta aos olhos a impossibilidade de, a priori, identificarem-se todos os casos pendentes no país que teriam, potencialmente, a mesma ratio! Entretanto, é possível suspenderem-se casos idênticos, que poderão (= deverão) ser decididos à luz de uma mesma tese!

A tese deve ser precisa e apta a gerar maior segurança jurídica no tratamento de casos repetitivos. Cabe aos tribunais especial atenção para que o texto da tese observe os limites estritos do que foi julgado, sem pretender indevidamente alcançar outras situações não veiculadas e discutidas nos casos-piloto. A criação de tese jurídica que não corresponda a situações julgadas é ilegítima e, por isso, não cumpre seu papel de representar uma hipótese de incidência da ratio decidendi.

A partir das considerações feitas acima, nossas conclusões são no sentido de que o âmbito de vinculatividade da decisão dos precedentes 1.696.396/MT e 1.704.520/MT, diz respeito, exclusivamente, a se considerar cabivel o agravo de instrumento contra decisões que versam sobre a competência.

A ausência de taxatividade "rígida, ou a taxatividade "mitigada" seria a ratio da decisão, a ser extraída, como de ordinário acontece, pelo juiz subsequente, ao examinar a decisão antecedente para, a

41 REsp 1.483.930/DF, rel. Min. Luis Felipe Salomão, 2aㅗ Seção, DJe de 01/02/2017.

42 Ratio decidendi $x$ tese jurídica. A busca pelo elemento vinculante do precedente brasileiro, RePro, São Paulo, v. 265, pp. 419-441, mar./2017. p. 428.

43 Expressão usada por Marino Marinelli. I precedenti giudiziari tra obbligatorietà e persuasività: note comparatistiche e riflessioni sparse a margine del nuovo CPC brasiliano e della sua sumula vincolante. RePro, São Paulo, no prelo. 
seu juízo, aplicá-la (ou não) ao caso que tem que decidir, ou seja, a qualquer outro caso concreto em que o problema seja o de saber se cabe ou não agravo de instrumento.

Na verdade, a nosso ver, quando se decide um recurso afetado como repetitivo, se fixa a tese com base na qual esse recurso será decidido, que é vinculante relativamente àqueles que, eventualmente, teriam tido seus procedimentos sobrestados, e também aos casos idênticos que vierem a ocorrer depois. Não se pode decidir o caso e criar regra no sentido de que a razão determinante que serviu de base à decisão do recurso servirá também para decidir-se os casos Y, Z, H. Isto é função do juiz subsequente. ${ }^{44}$

O regime dos repetitivos se presta, como observamos, antes, a resolver predominantemente questões de massa, questões que se repetem de modo absolutamente idêntico e, como se trata de recurso, aplica-se, por óbvio, o princípio dispositivo: julga-se aquilo que é objeto do recurso e nada mais.

Retomando as principais ideias apenas manifestadas:

1) O que vincula no regime dos recursos repetitivos, aprimorado pelo CPC de 2015 é a tese e não a ratio.

2) A tese é mais específica que a ratio - é a resolução daquele caso.

3) Não poderia ser de outro modo, já que se trata de recurso, submetido ao princípio dispositivo: não se pode decidir mais do que aquilo que foi submetido à apreciação do tribunal.

Com mais razão ainda não vinculam as manifestações constantes do acórdão a título de obter dictum: é o caso da afirmação que se faz, nas decisões dos recursos 1.696.396/MT e 1.704.520/MT,sobre o não cabimento do mandado de segurança.

As decisões judiciais também são compostas pelos obiter dicta ou gratis dicta. Esses termos significam, literalmente: o que é dito para morrer, ou en passant. Tudo o que é dito numa decisão e que não integra a ratio decidendi é obiter dicta, e o que é dito obiter dicta tem um peso meramente persuasivo. ${ }^{45}$

A regra (rule - o cerne ou o núcleo do precedente) é equivalente à ratio decidendi, os obiter dicta são argumentos ou comentários que gravitam em torno da ratio que, via de regra, não aparece, no acórdão, de forma explícita e expressa.

É claro que aqui o conceito de ratio decidendi está sendo drasticamente simplificado. Sabe-se, todavia, que existe grande discussão na doutrina anglo-saxônica a respeito do conceito de ratio e também sobre o "teste" a ser utilizado para se identificar uma ratio. ${ }^{46}$

Se ocorre de um caso novo (case of first impression) ter que ser decidido por um juiz inglês, a sua decisão consistirá num precedente, mas dificilmente se determina, na própria decisão, que parte dela

44 É o dever de adstrição ao mérito do recurso. "O dever de adstrição deve ser compreendido como uma vedação do órgão formador do precedente de abstrair o caso concreto e formular, pela via jurisdicional, conclusões decorrentes de situações hipotéticas não existentes na situação litigiosa posta em juízo e, a partir delas, estabelecer normas precedentes ou sumuladas.

Em outras palavras, faz-se necessária a adstrição ao caso concreto quando da edição de súmulas ou precedentes qualificados, devendo ser observado, portanto, quando da formação desses pronunciamentos, o princípio da congruência ou correlação. O princípio da congruência ou correlação (art. 2. ํㅡㅇ CPC), em seu sentido clássico, impossibilita o juiz de, em sua decisão, ampliar ou modificar os contornos da pretensão do autor.

Tal limitação é expressa no art. 141 do CPC e consiste em uma decorrência da inércia jurisdicional, segundo a qual o Poder Judiciário não age senão quando provocado e nos limites da provocação, sendo, dessa feita, vedado ao magistrado extrapolar esses limites, julgando matéria para a qual não tenha sido provocado.

Portanto, o juiz, quando de seu julgamento, deve se ater aos limites propostos pelas partes, sendo, por via de consequência, vedado a ele conhecer de matéria ou julgar questões que não lhe foram apresentadas pelas partes interessadas". (Fábio Victor da Fonte Monnerat. Súmulas e precedentes qualificados: técnicas de formação e aplicação. São Paulo: Saraiva Educação, 2019 , p. 76-77).

45 "It is a truism upon which there is no need to enlarge that dicta are of varying degrees of persuasiveness". Rupert Cross; J. W. Harris. Precedent in English law. 4. ed. Oxford: Clarendon Press Publishing, 1991. p. 76.

46 Neil Andrews, Reporting Case Law: unreported cases, the definition of a ratio and the criteria for reporting decisions, in Legal Studies, 5, 1985, The Journal of the Society of Public Teachers of Law, Butterworths, pp. 205-232, especialmente p. 210. A ideia do "teste" é muito interessante e está bastante presente na doutrina inglesa: formulam-se algumas perguntas para se ter certeza de que o objeto que se tem à frente é mesmo aquele a que corresponde o conceito antes formulado. 
deve ser considerada a ratio decidendi. ${ }^{47}$ Por outro lado, o que normalmente ocorre é que a rule seja definida pela decisão posterior, ou seja, é a decisão subsequente que determina os contornos da ratio (= holding, core $)^{48}$

A afirmação que se faz, nos acórdãos, no sentido do não cabimento do mandado de segurança contra as decisões que o próprio acórdão considera agraváveis, justamente porque seriam recorríveis, embora seja harmônica e coerente com o resto da decisão, não é nem ratio, nem tese: é obter dictum e, portanto, desprovida de força vinculativa.

\section{Referências}

ANDREWS, Neil. Reporting Case Law: unreported cases, the definition of a ratio and the criteria for reporting decisions, in Legal Studies, 5, 1985, The Journal of the Society of Public Teachers of Law, Butterworths, pp. 205-232.

ARRUDA ALVIM NETTO, José Manoel de. Notas a respeito dos aspectos gerais e fundamentais da existência dos recursos - Direito brasileiro. RePro 48/7-26.

ARRUDA ALVIM WAMBIER, Teresa. Mandado de segurança, medida cautelar e ato judicial. 3. ed. São Paulo: RT, 1994.

ARRUDA ALVIM WAMBIER, Teresa; SATO, Priscila Kei. O princípio da translatio iudicii e a competência das Justiças Federal e Estadual. In: GUSMÃO, José Roberto d'Affonseca (org.). Temas de propriedade intelectual: 25 anos de Gusmão Ẽ Labrunie. São Paulo: Gusmão \& Labrunie Advogados, 2013, p. 465-506.

AURELLI, Arlete Inês. Impactos no novo CPC sobre o mandado de segurança. In: LUCON, Paulo Henrique dos Santos (coord. et. al.). Processo em jornadas. Salvador: Juspodivm, 2016,

BARROSO, Luís Roberto; MELlO, Patrícia Perrone Campos. O papel criativo dos Tribunais. In: MENDES, Aluisio Gonçalves de Castro; DINAMARCO, Cândido Rangel; PINHO, Humberto Dalla Bernardina de; FUX, Luiz (Coord.). Estudos de Direito Processual em homenagem a Paulo Cézar Pinheiro Carneiro. Rio de Janeiro: GZ Editora, 2019.

BARROSO, Luís Roberto; MELLO, Patrícia Perrone Campos. Trabalhando com uma nova lógica: a ascensão dos precedentes no direito brasileiro. Revista da AGU, Brasília, v. 15, n. 03, p. 09-52, jul.-set. 2016.

BUZAID, Alfredo. Do mandado de segurança, $R F$ 164/13, 6 .

CABRAL, Antonio do Passo. A técnica do julgamento-alerta na mudança de jurisprudência consolidada. RePro, São Paulo, v. 38, n. 221, p.13-48, jul./2013.

CALMON DE PASSOS, J. J.. Mandado de segurança contra atos jurisdicionais: tentativa de sistematização nos cinqüenta anos de sua existência. RePro, São Paulo, v. 9, n. 33, p. 47-69, jan./ mar. 1984.

CARNEIRO, Athos Gusmão. Da antecipação de tutela. 7. ed. Rio de Janeiro: Forense, 2010.

CARPES, Arthur Thompsen. A taxatividade mitigada do art. 1.015 do CPC: notas sobre a ratio decidendi fixada no STJ na perspectiva da teoria das normas. RePro, São Paulo, v. 294, p. 227-247, ago./2019.

CARVAlHO, Pedro Leonel Pinto de. Segurança e recurso contra ato jurisdicional, RePro 32/315-317.

CROSS, Rupert; HARRIS, J. W.. Precedent in English law. 4. ed. Oxford: Clarendon Press Publishing, 1991.

DWORKIN, Ronald. Taking Rights Seriously. Cambridge, Massachussets: Harvard University Press, 1978.

47 Rupert Cross e J. W. Harris. Op cit., p. 42.

48 Ronald Dworkin. Taking Rights Seriously. Cambridge, Massachussets, Harvard University Press, 1978 , p. 111. 
FERRAZ, Taís Schilling. Ratio decidendi x tese jurídica. A busca pelo elemento vinculante do precedente brasileiro, RePro, São Paulo, v. 265, pp. 419-441, mar./2017..

KLAPPSTEIN, Verena. Schriften zur Rechstheorie Heft 243, Die Rechtsprechungänderung mit Wirkung fur die Zukunft. Berlin: Duncker \& Humblot, 2008.

LACERDA, Galeno. Comentários ao Código de Processo Civil. V. VIII, t. I. 3. ed. Rio de Janeiro: Forense, 1987

LAMOND, Grant. Precedent, Philosophy Compass, v. 2, n. 5, pp. 699-711, set./2007.

MARANHÃO, Clayton. Agravo de instrumento no Código de Processo Civil de 2015: entre a taxatividade do rol e um indesejado retorno do mandado de segurança contra ato judicial. RePro, São Paulo, v. 256/2016, p. 147-168.

MARINELLI, Marino. I precedenti giudiziari tra obbligatorietà e persuasività: note comparatistiche e riflessioni sparse a margine del nuovo CPC brasiliano e della sua sumula vincolante. RePro, São Paulo, no prelo.

MEDINA, José Miguel Garcia. Novo Código de Processo Civil comentado. 5. ed. São Paulo: RT, 2017.

MONNERAT, Fábio Victor da Fonte. Súmulas e precedentes qualificados: técnicas de formação e aplicação. São Paulo: Saraiva Educação, 2019.

NEVES, Daniel Amorim Assumpção. Ações constitucionais. 3. ed. Salvador: Juspodivm, 2017.

NUNES, José de Castro. Do mandado de segurança. 7. ed. Rio de Janeiro: Forense, 1967.

PEREIRA, Carlos Frederico Bastos. Interpretação extensiva, analogia e o rol do artigo 1.015 do Código de Processo Civil. RePro, São Paulo, v. 282, p. 267-284, ago./2018.

ROCHA, Henrique de Moraes Fleury da. Cabimento do agravo de instrumento segundo o Código de Processo Civil brasileiro de 2015: aspectos polêmicos. RePro, São Paulo, v. 282, p. 299-317, ago./2018.

ROMÃO, Pablo Freire. Taxatividade do rol do art. 1.015, do NCPC: mandado de segurança como sucedâneo do agravo de instrumento? RePro, São Paulo, v. 259/2016, p. 259-273.

SALLES, Carlos Alberto de. Mandado de segurança contra atos judiciais. In: ARRUDA ALVIM WAMBIER, Teresa; ARRUDA ALVIM, Eduardo; BUENO, Cassio Scarpinella (coords.). Aspectos polêmicos e atuais do mandado de segurança - 51 anos depois. São Paulo: RT, 2002.

SANTOS, Evaristo Aragão. Em torno do conceito e da formação do precedente judicial. In: ARRUDA ALVIM WAMBIER, Teresa (Coord.). Direito jurisprudencial. São Paulo: RT, 2012.

SATO, Priscila Kei. Translatio iudicii no direito processual civil brasileiro. Tese de Doutorado. Pontifícia Universidade Católica de São Paulo, 2010.

SILVA, Ovídio A. Baptista da. Do processo cautelar. 3. ed. Rio de Janeiro: Forense, 2006

THEODORO JR., Humberto. Processo cautelar. São Paulo: Leud, 1983

VELLOSO, Carlos Mário. Direito líquido e certo e decadência. In: FERRAZ, Sergio (org.). Mandado de segurança. Porto Alegre: Fabris/IAB, 1986.

VIDIGAL, Luis Eulálio de Bueno. Mandado de segurança. São Paulo: Saraiva, 1965

WALD, Arnoldo. O mandado de segurança na prática judiciária. Rio de Janeiro: Forense, 1968. 